\title{
AUDIT KEPATUHAN PENGELOLAAN PIUTANG DALAM MEMINIMALISIR PIUTANG TAK TERTAGIH (Studi Kasus PT Bank Negara Indonesia (Persero) Tbk Cabang Makassar)
}

\author{
Ismawati \\ Fakultas Ekonomi dan Bisnis \\ Universitas Muhammadiyah Makassar \\ Email: ismawati@unismuh.ac.id \\ Naidah \\ Fakultas Ekonomi dan Bisnis \\ Universitas Muhammadiyah Makassar \\ Email: naidahusain@yahoo.com \\ Linda Arisanty Razak \\ Fakultas Ekonomi dan Bisnis \\ Universitas Muhammadiyah Makassar \\ Email: lindarazak@unismuh.ac.id
}

\begin{abstract}
This research aims to know the application of the compliance audit in the management of accounts receivable accounts receivable to minimise not collectible at PT. Bank Negara Indonesia (Persero) Tbk. Makassar Branch. Methods of analysis used in this study is a qualitative method of analysis. In this case the researchers are using a risk-based audit approach, i.e. audit approach where checking is done against the harmony between the policy and the procedures are carried out with the provision of regulation. So, PT Bank Negara Indonesia (Persero) Tbk. Makassar Branch should be in line with regulations or procedures that have been held by Bank Indonesia (BI) in terms of financing. Based on the results of the study, pointed out that Compliance Audits conducted by the Director of compliance and Compliance Work Unit PT Bank Negara Indonesia (Persero) Tbk. Makassar Branch has gone well in accordance with the duties and those powers and keep independensinya properly because it had working guidelines, systems and procedures of work refers to the provisions of the applicable legislation. As well as in terms of the management of accounts receivable to the customer were in accordance with the applicable procedures. Each of these stages did not escape from the supervision of the compliance group so that each part or section associated on the stage professionally responsible.
\end{abstract}

Keyword: Compliance Audit, accounts receivable, accounts receivable is not collectible

\begin{abstract}
Abstrak
Penelitian ini bertujuan untuk mengetahui penerapan audit kepatuhan dalam pengelolaan piutang untuk meminimalisir piutang tak tertagih pada PT. Bank Negara Indonesia (Persero) Tbk. Cabang Makassar. Metode analisis yang digunakan dalam penelitian ini adalah metode analisis kualitatif. Dalam hal ini peneliti menggunakan pendekatan audit berbasis risiko, yaitu pendekatan audit dimana dilakukan pengecekan terhadap keselarasan antara kebijakan dan prosedur yang dilakukan dengan ketetapan regulasi. Jadi, PT. Bank Negara Indonesia (Persero) Tbk. Cabang Makassar harus sejalan dengan peraturan atau prosedur yang telah diadakan oleh Bank Indonesia (BI) dalam hal pembiayaan. Berdasarkan hasil penelitian, menunjukkan bahwa Audit Kepatuhan yang dilaksanakan oleh Direktur Kepatuhan dan Satuan Kerja Kepatuhan PT. Bank Negara Indonesia (Persero) Tbk. Cabang Makassar telah berjalan dengan baik sesuai dengan tugas dan kewenangannya dan menjaga independensinya dengan baik karena memiliki pedoman kerja, sistem dan prosedur kerja yang telah mengacu kepada ketentuan perundang-undangan yang berlaku. Begitupun dalam hal pengelolaan piutang kepada nasabah telah sesuai dengan prosedur yang berlaku. Setiap tahapan tersebut tidak luput dari pengawasan Grup Kepatuhan agar setiap bagian atau seksi yang terkait pada tahapan tersebut bertanggung jawab secara profesional.
\end{abstract}

Kata Kunci : Audit Kepatuhan, Piutang, piutang tak tertagih 


\section{PENDAHULUAN}

Dana merupakan aspek penting bagi pemenuhan manusia yang mana dibutuhkan usaha lebih untuk memperolehnya. Kerja keras dan optimalisasi kerja terkadang tidak dapat memenuhi kebutuhan tersebut, hal ini disebabkan karena dana bukan saja digunakan untuk kebutuhan sehari-hari, namun juga untuk memulai suatu aktivitas/tindakan. Dalam bisnis, pihak yang sangat merasakan kurangnya dana untuk menjalankan usaha adalah pengusaha kecil dan menengah. Salah satu solusi untuk memenuhi kebutuhan dana tersebut adalah dengan melakukan pinjaman/kredit kepada instansi atau lembaga keuangan seperti bank.

Memasuki dekade industri jasa pembiayaan/perkreditan di Indonesia mengalami perkembangan yang sangat pesat sehingga menuntut industri ini dapat menyesuaikan diri dengan kebutuhan masyarakat terhadap pelayanan jasa keuangan yang sangat kompleks. Dalam menjalankan kegiatan penyaluran kredit tersebut terdapat berbagai prosedur yang mendasarinya. Adapun prosedur-prosedur tersebut merupakan rangkaian kegiatan yang harus dilakukan sebagai proses jalannya permohonan kredit hingga sampai kredit tersebut dicairkan. Secara umum prosedur pemberian kredit meliputi: (a) Permohonan kredit; (b) Evaluasi atau analisis pemberian kredit; (c) Keputusan pemberian kredit; (d) Perjanjian kredit; dan (e) Pencairan kredit.

Kendala terbesar dari pemberian kredit adalah tingginya resiko piutang tak tertagih (bad debt) yang akan timbul dari pelayanan jasa keuangan, dimana hal tersebut akan menghambat kegiatan ekonomi/ bisnis dari lembaga/ perusahaan pembiayaan tersebut.
Timbulnya piutang tak tertagih akan menyebabkan arus kas perusahaan menjadi tidak sehat yang berdampak terhadap profit dan kesehatan perusahaan. Terdapat berbagai faktor yang menyebabkan timbulnya piutang tak tertagih baik faktor eksternal dan internal perusahaan. Faktor eksternal yang terjadi pada suatu perusahaan pembiayaan dapat dipengaruhi oleh kondisi ekonomi secara makro, sedangkan dari sisi internal dapat disebabkan oleh terjadinya pemisahan wewenang yang tidak tegas dari para pegawai, prosedur pemberian kredit yang tidak jelas, pegawai yang tidak kompeten, lemahnya system pengawasan dan lain sebagainya.

Piutang tak tertagih merupakan masalah yang dialami oleh semua lembaga keuangan yang memberikan fasilitas pinjaman akibat dari suatu akad perjanjian dan tidak mungkin untuk menghilangkan masalah ini. Permasalahan piutang tak tertagih ini dapat timbul pada saat pertama kali diberikannya kredit, seperti dikarenakan sistem cairnya dana lebih cepat dari lembaga keuangan bank, yang menyebabkan credit checking kurang terkendali sehingga terjadi penyimpangan. Selain itu piutang tak tertagih dapat disebabkan oleh kredit yang bermasalah ditengah masa perkreditan, misalnya seperti seorang debitur mendapatkan kesulitan keuangan sehingga pembayaran kewajiban atas kredit tidak dapat dilakukan sesuai dengan ketentuan yang telah disepakati bersama sebelumnya, dan bisa juga diakibatkan bencana alam maupun suatu kejadian lainnya yang mana menghambat berjalannya proses bisnis debitur dan tentunya akan berdampak langsung kepada perusahaan pembiayaan sebagai 
kreditur dengan tidak dapat dipenuhinya kewajiban debitur kepada kreditur.

Penelitian yang dilakukan oleh Manik Cahyarini (2015) dalam penelitiannya yang berjudul Analisis Umur Piutang untuk Meminimalisir Piutang Tak Tertagih Pada PT Bisma Karaeng Pilang Surabaya, dengan mengetahui batas jatuh tempo pelunasan piutang usaha, maka harus dibuat analisis umur piutang yang akan digunakan untuk menghitung umur batas penagihan sehingga di dalam pelunasan piutang dapat diketahui mana yang masih menunggak, penentuan umur piutang adalah bilamana suatu piutang tidak dapat ditagih setelah melewati tanggal jatuh tempo maka akan terjadi resiko piutang tidak dibayar. Makin lama umur piutang yang tidak tertagih makin besar resiko piutang tersebut tidak terbayar.

Hal ini sama dengan penelitian yang dilakukan oleh Anny Widiasmara (2014) yang berjudul Analisis Pengendalian Intern Piutang Usaha Untuk Memenimalkan Piutang Tak Tertagih, dengan dilakukannya pengendalian intern terhadap piutang usaha, kualitas penagihan mengalami perbaikan terus menerus maka dapat meminimalkan piutang tak tertagihnya dan berhasil membukukan profit sesuai dengan tujuan yang ditetapkan oleh perusahaan. Untuk memastikan bahwa kegiatan operasional dari yang meliputi kegiatan penyaluran kredit tersebut telah sesuai dengan prosedur-prosedur pemberian kredit maka perlu dilakukan audit kepatuhan/ketaatan.

Audit kepatuhan/ ketaatan ini sendiri berfungsi untuk menilai apakah kegiatan pemberian kredit sudah sesuai dengan prosedur yang ada. Dengan dipatuhinya semua prosedur dari tata cara sistem pemberian kredit tersebut maka akan dapat menghindarkan dari kemungkinan adanya penyimpanganpemyimpangan ataupun terjadinya kredit macet yang hingga sampai saat ini masih sering terjadi. Selain itu, audit kepatuhan/ketaatan ini juga dapat digunakan untuk menunjang terwujudnya efektivitas kegiatan pemberian kredit.

PT. Bank Negara Indonesia (Persero) Tbk. Cabang Makassar adalah salah satu perusahaan BUMN terkemuka yang mendapatkan peringkat "sangat bagus" namun memiliki catatan kenaikan tingkat bad debt yang cukup tinggi setiap bulannya dilihat dari KPI (Key Performance Indicator) nasional perusahaan. Hal tersebut sangat menganggu portfolio perusahaan. Untuk menyingkapi hal tersebut yang menjadi fokus dalam menangani piutang tak tertagih yaitu bukanlah bagaimana cara untuk menghilangkan piutang tak tertagih tersebut, akan tetapi mengarah kepada bagaimana cara memperkecil timbulnya piutang tak tertagih.

Audit kepatuhan dilaksanakan untuk mengadakan review secara sistematik terhadap bagian dari prosedur dan metode operasi suatu organisasi untuk menilai efesiensi dan efektifitasnya. Objektivitas utama audit kepatuhan atas penerimaan kas dari piutang usaha adalah untuk menetukan apakah perusahaan telah menjalankan prosedurprosedur yang terkait dengan pengiriman dan penerimaan kas sesuai dengan kondisi, peraturan, dan undang-undang tertentu secara efesien dan efektif. Audit kepatuhan tidak terbatas pada pemeriksaan ketaatan pelaksanaan sistem dan prosedur yang sudah ada, tetapi juga memberikan saran perbaikan bagi perusahaan yang diaudit. 
Semakin baik suatu sistem dan prosedur, maka akan semakin baik dalam menanggulangi piutang tak tertagih yang timbul dan sebaliknya jika sistem dan prosedur tersebut tidak baik, maka akan berdampak fatal terhadap piutang tak tertagih yang timbul. Sehingga dapat dilihat bahwa suatu sistem dan prosedur perusahaan akan sangat menentukan jalannya perusahaan. Sistem pengendalian piutang diharapkan banyak memberikan manfaat bagi suatu perusahaan pembiayaan dalam meminimalisasi bad debt.

\section{TINJAUAN PUSTAKA}

\subsection{Pengertian Audit}

Menurut Agoes (2012:2) Auditing adalah jasa yang diberikan oleh auditor dalam memeriksa dan mengevaluasi laporan keuangan yang disajikan perusahaan klien. Pemeriksaan ini tidak dimaksudkan untuk mencari kesalahan atau menemukan kecurangan, walaupun dalam pelaksanaannya sangat memungkinkan diketemukannya kesalahan atau kecurangan. Dari berbagai definisi diatas, terdapat beberapa karakteristik dalam pengertian auditing yaitu:

1. Informasi yang dapat diukur dan kriteria yang telah ditetapkan

2. Entitas Ekonomi (Economy Entity)

3. Aktivitas Mengumpulkan dan Mengevaluasi Bahan Bukti

4. Independensi dan Kompetisi Auditor Pelaksana

5. Pelaporan Audit

\subsection{Jenis - Jenis Audit}

Agoes (2012:10) ditinjau dari luas pemeriksaannya, audit bisa dibedakan atas:

\section{a. Pemeriksaan umum (General Audit)}

Suatu pemeriksaan umum atas laporan keuangan yang dilakukan oleh KAP independen dengan tujuan untuk bias memberikan pendapat mengenai kewajaran laporan keuangan secara keseluruhan

\section{b. Pemeriksaan Khusus (Special Audit)}

Suatu pemeriksaan terbatas (sesuai dengan permintaan Audit) yang dilakukan oleh KAP yang independen dan pada akhir pemeriksaannya auditor tidak perlu memberikan pendapa terhadap kewajaran laporan keuangan secra keseluruhan pendapat yang diberikan terbats pada pos atau masalah tertentu yang diperiksa, karena prosedur audit yang dilakukan juga terbatas.

Agoes (2012:11) ditinjau dari jenis pemeriksaan, audit bisa dibedakan atas:

a. Management Audit(Operatinal Audit)

Suatu pemeriksaan terhadap kegiatan operasi suatu perusahaan, termasuk kebijakan akuntanssi dan kebijakan operasional yang telah ditentukan oleh manjemen, untuk mengetahui apakah kegiatan operasi tersebut sudah dilakukan secara efektif, efesien dan ekonomis.

b. Audit Kepatuhan (Compliance Audit)

Pemeriksaan yang dilakukan untuk mengetahui apakah perusahaan sudah menaati peraturan-peraturan dan kebijakan-kebijakan yang berlaku, baik yang ditetapkan oleh pihak intern perusahaan (Manajemen, Dewan Komisaris) Maupun Pihak Eksternal (Pemerintah, Bapepam LK, Bank Indonesia, Direktorak Jendral Pajak, dan lain-lain).

c. Pemeriksaan Intern (Internal Audit)

Pemeriksaan yang dilakukan oleh bagian internal audit perusahaan, baik terhadap laporan keuangan dan catatan akuntansi perusahaan, maupun ketaatan 
terhadap kebijakan manajemen yang telah ditentukan.

\section{d. Computer Audit}

Pemeriksaan oleh KAP terhadap perusahaan yang memproses data akuntasinya dengan menggunakan Electronic Data Processing (EDP) System.Sedangkan berdasarkan kelompok atau pelaksana audit, audit dibagi 4 jenis yaitu:

1. Auditor Ekstern

2. Auditor Intern

3. Auditor Pajak

4. Auditor Pemerintah

\subsection{Tujuan dan Manfaat Audit}

Audit dikembangkan dan dilaksanakan karena audit memberi banyak manfaat bagi dunia bisnis. Pelaksaanaan audit mempunyai tujuan yang berbeda, beberapa tujuan audit adalah:

1. Penilaian Pengendalian (Appraisal of Control)

2. Penilaian Kinerja ( Appraisal of Performance)

3. Membantu Manajemen (Assistance to Manajement)

\subsection{Norma Pelaksanaan Audit}

Norma Pelaksanaan audit adalah pedoman bagi akuntan publik dalam menilai kualitas hasil pekerjaan dan mengukur tingkat tanggung jawab akuntan. Secara baku norma yang menjadi ukuran pekerjaan auditor tersebut ditetapkan oleh organisasi akuntan profesional, contohnya Generally Accepted Auditing Standards (GAAS).

a. Norma Umum

b. Norma Pelaksanaan Audit

c. Norma Pelaporan

\subsection{Pengertian Audit Kepatuhan}

Menurut Agoes

(2012:14)

mendefenisikan bahwa Compliance Audit adalah pemeriksaan yang dialkukan untuk mengetahui apakah perusahaan sudah mentaati peraturan-peraturan dan kebijakan-kebijakan yang berlaku,baik yang ditetapkan oleh pihak intern perusahaan maupun pihak ekstern perusahaan. Audit kepatuhan dilakukan dengan cara:

1) Pengujian adanya kepatuhan

a. Pengujian transaksi dengan mengikuti pelaksanaan transaksi tertentu.

b. Pengujian transaksi tertentu yang telah terjadi dan yang telah dicatat.

2) Pengujian dalam tingkat kepatuhan

Auditor tidak hanya berkepentingan dengan eksistensi pengendalian internal, tetapi juga berkepentingan pada kepatuhan klien terhadap pengendalian internal. Prosedurnya adalah:

a. Sampel diambil dari dokumen populasi, lalu memeriksa dokumen pendukungnya.

b. Pengujian substansi,

\subsection{Tujuan Audit Kepatuhan}

Menurut Mulyadi (2010:32) tujuan audit kepatuhan adalah untuk menentukan apakah yang diaudit sesuai dengan kondisi atas perusahaan tertentu. Dalam penjelasan Agoes (2012:14) menyatakan bahwapulkan bahwa tujuan audit kepatuhan yaitu:

1. Menilai tingkat kepatuhan yang dilakukan oleh setiap fungsi dalam suatu organisasi dan perusahaan.

2. Meminimalisir terjadinya pelanggaran terhadap peraturan yang diterapkan didalam suatu organisasi dan perusahaan. 
3. Meningkatkan kinerja organisasi dan perusahaan.

\subsection{Kriteria Audit Kepatuhan}

Kriteria yang ditetapkan dalam pelaksanaan audit kepatuhan, misalnya adalah kebijakan, peraturan, persyaratan, pinjaman kredit, prosedur yang ditetapkan. Informasi terukur dalam audit kepatuhan seperti data mengenai pelaksanaan kebijakan, peraturan, prosedur, pemberhentian pegawai, pelaporan SPT pajak dan pelaksanaannya. Kriteria audit kepatuhan dibagi menjadi 2 yaitu keriteria internal dan kriteria eksternal.

a. Kriteria internal

b. Kriteria eksternal

\subsection{Pengertian Piutang}

Menurut Agoes (2012:192) piutang usaha adalah piutang yang berasal dari penjualan barang dagangan atau jasa secara kredit. Tujuan utama dalam penjualan secara kredit ataua pemberian kredit yang dilakukan oleh suatu perusahaan adalah memberikan kelonggaran kepada konsumen untuk mengembalikan atau melunasi kredit tersebut sesuai dengan waktu yang telah ditentukan sehingga bagi perusahaan akan timbul suatu piutang. Piutang tersebut merupakan suatu klaim yang dimiliki oleh perusahaan untuk menuntut pembayaran dalam bentuk uang atau penyerahan aktiva kepada pihak debitur.

\subsection{Klasifikasi Piutang}

Pengelompokkan piutang dapat didasarkan pada 3 (tiga) hal yaitu berdasarkan asal transaksinya, bentuk dan jatuh temponya. Menurut Dedhy dan Yie Ke (2010), klasifikasi piutang adalah sebagai berikut:

a. Berdasarkan asal transaksi
1) Piutang usaha

2) Piutang

b. Berdasarkan bentuk

1) Piutang tanpa janji tertulis

2) Piutang dengan janji tertulis (piutang wesel)

c. Berdasarkan jatuh tempo

1) Piutang jangka pendek

2) Piutang jangka panjang

Sedangkan menurut PSAK No.9 piutang diklasifikasikan sebagi berikut: Menurut sumber terjadinya, piutang digolongkan dalam dua kategori yaitu piutang usaha dan piutang lain-lain. Dari pengertian pengelompokkan piutang diatas dapat disimpulkan bahwa piutang yang timbul dari pemberian kredit atau penjualan secara kredit merupaka piutang usaha.

\subsection{Pengakuan Piutang Usaha}

Pada saat perusahaan melakukan penjualan dan belum menerima kas sebagai hasil penjualan maka akan timbil suatu piutang usaha. Dalam transaksi bisnis yang berlaku umum, untuk mendapatkan pembayaran yang cepat atas piutang usaha biasanya penjual memberikan penawaran potongan penjualan (diskon) pada para pelanggan.

Pencatatan diskon dapat dilakukan dengan menggunakan 2 (dua) metode yaitu metode bersih (net method) dan metode bruto (gross method).

1. Net method

2. Gross method

Selain diskon atas pembayaran (cash discount) terdapat juga trade discount yaitu diskon yang nilainya langsung dipotongkan pada harga jual dengan tujuan adanya peningkatan volume penjualan.

Menurut PSAK No.9 piutang dinyatakan sebesar jumlah kotor tagihan dikurangi dengan taksiran jumlah yang 
tidak dapat ditagih. Jumlah kotor piutang harus tetap disajikan pada neraca diikuti dengan penyisihan untuk pitang yang diargukan atau taksiran jumlah yang tidak dapat ditagih.

\subsection{Pengertian Piutang Tak Tertagih}

Adanya piutang dalam kegiatan perusahaan memungkinkan terjadinya keadaan dimana piutang tersebut tidak dilunasi (bad debt). Perusahaan akan sangat dirugikan oleh adanya piutang tak tertagih. Dengan adanya hal tersebut, maka perusahaan diharapkan menetapkan suatu kebijakan atas masalah piutang tidak tertagih.

Piutang tak tertagih ini biasanya oleh pihak perusahaan menetapkan persentase tertentu untuk menggambarkan seberapa besar pengaruhnya terhadap kondisi keuangan perusahaan. Biasanya pengenaan persentasenya ditentukan berdasarkan umur piutang tersebut dan berdasarkan pengalaman periode yang lalu.

\subsection{Jenis-jenis Piutang TakTertagih}

Jenis-jenis piutang tak tertagih diantaranya:

1. Kredit dalam perhatian khusus Merupa

2. Kredit kurang lancar

3. Kredit dirugakan

4. Kredit macet.

\subsection{Faktor-faktor PiutangTakTertagih}

Hampir setiap perusahaan pernah mengalami masalah piutang tak tertagih. Gejala kredit macet antara lain disebabkan oleh:

1. Menurunnya Pendapatan Bersih

2. Menurunnya Penjualan secara Tajam

3. Menurunnya Perputaran Persediaan

4. Meningkanya Penjualan secara Tajam

5. Menurunnya Perputaran Piutang
Menurut Rivai, dkk (2013), kredit macet atau piutang tak tertagih dapat disebabkan oleh beberapa faktor yaitu:

1. Faktor Internal, yaitu faktor-faktor yang berasal dari pihak kreditur.Faktor-faktor tersebut diantaranya:

a. Keteledoran dari pihak kreditur

b. Terlalu mudah memberikan piutang

c. Konsentrasi piutang pada sekelompok pengguna jasa Kurang memadainya jumlah eksekutif dan staf bagian piutang.

d. Lemahnya bimbingan dan pengawasan pimpinan kepala para eksekutif dan staf bagian piutang.

2. Lemahnya perusahaan mendeteksi timbulnya piutang macet

3. Faktor Eksternal,yaitu faktor-faktor yang berasal dari pihak debitur. Faktor-faktor tersebut diantaranya:

a. Menurunnya kondisi ekonomi perusahaan yang disebabkan merosotnya kondisi ekonomi umum dana atau bidang usaha dimana mereka beroperasi.

b. Adanya salah arus dalam pengelolaan usaha bisnis perusahaan atau karena kurang pengalaman dalam bidang usaha yang ditangani.

c. Problem keluarga, misalnya perceraian, kematian, sakit berkepanjangan,pemborosan dana oleh salah satu atau beberapa anggota keluarga debitur.

Penyebab kesulitan keuangan dapat dikategorikan menjadi 2, yaitu:

1. Faktor-faktor intern, adalah faktorfaktor yang ada dalam diri perusahaan sendiri. Dari segi managerial faktor terjadinya kredit macet disebabkan oleh: 
a. Kelemahan dalam kebijaksanaan pembelian dan pengeluaran

b. Tidak efektifnya control atas biaya dan pengeluaran

c. Kebijaksanaan tentang kebijakan piutang yang tidak efektif

2. Faktor-faktor ekstern, adalah faktorfaktor yang berasal dari luar perusahaan, diantaranya:

a. Bencana alam, adalah sesuatu yang tidak kita inginkan, misalnya: kebakaran, gempa bumi, gunung meletus, angina topan, banjir dll.

b. Peperangan, merupakan pengrusakan dari akibat permasalahan, misalnya: demonstrasi, pembakaran, dll.

\subsection{Kerangka Konsep}

Piutang tak tertagih merupakan masalah yang dialami oleh semua lembaga keuangan yang memberikan fasilitas pinjaman akibat dari suatu akad perjanjian dan tidak mungkin untuk menghilangkan masalah ini. Untuk memastikan bahwa kegiatan operasional dari yang meliputi kegiatan penyaluran kredit tersebut telah sesuai dengan prosedur-prosedur pemberian kredit maka perlu dilakukan audit kepatuhan/ketaatan.

Audit kepatuhan/ketaatan ini sendiri berfungsi untuk menilai apakah kegiatan pemberian kredit sudah sesuai dengan prosedur yang ada. Dengan dipatuhinya semua prosedur dari tata cara sistem pemberian kredit tersebut maka akan dapat menghindarkan dari kemungkinan adanya penyimpanganpemyimpangan ataupun terjadinya kredit macet yang hingga sampai saat ini masih sering terjadi.

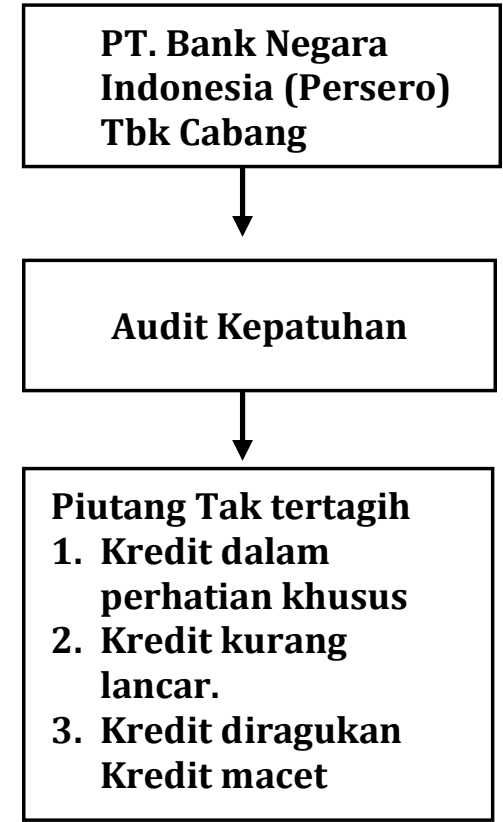

Gambar 2.1

Kerangka Konsep

\section{METODE PENELITIAN}

\subsection{Jenis Penelitian}

Jenis penelitian yang digunakan dalam penelitian ini adalah penelitian deskriptif kualitatif. Metode deskriptif yaitu penelitian yang berusaha untuk menuturkan pemecahan masalah yang ada sekarang berdasarkan data-data, menganalisis dan menginterpretasi, juga bisa bersifat komperatif dan korelatif.

Peneliti melakukan penelitian terhadap penerapan Audit Kepatuhan dalam pengelolaan piutang tak tertagih pada PT. Bank Negara Indonesia (Persero) Tbk. Cabang Makassar dimulai dengan mengamati, menelusuri dan mengumpulkan serta menyaring seluruh keterangan yang masuk secara menyeluruh dan secara detail kemudian diuraikan sehingga diperoleh gambaran dari hasil yang jelas. Penelitian ini merupakan penelitian yang menggunakan studi kasus dan menggunakan jenis penelitian deskriptif maka dalam 
penelitian ini tidak menggunakan hipotesis.

\subsection{Fokus Penelitian}

Penelitian ini dilakukan untuk mengetahui bagaimana penerapan Audit Kepatuhan dalam pengelolaan piutang untuk meminimalisir piutang tak tertagih pada PT. Bank Negara Indonesia (Persero) Tbk. Cabang Makassar,apakah audit kepatuhan telah berfungsi dalam meminimalisir piutang tak tertagih pada perusahaan.

\subsection{Pemilihan Lokasi dan Situs Penelitian}

Penelitian ini akan dilaksanakan dalam jangka waktu selam 2 bulan dimulai sejak bulan April sampai bulan Juni 2018 atau setelah seminar proposal dilaksanakan. Dan penelitian ini dilaksanakan di PT. Bank Negara Indonesia (Persero) Tbk. Cabang Makassar dengan pertimbangan bahwa perusahaan tersebut salah satu perusahaan yang menjalankan usahanya dengan cara pemberian kredit.

\subsection{Sumber Data}

Sumber data yang digunakan untuk memperoleh data dalam penelitian ini yaitu :

1. Data primer

Data primer merupakan data yang diperoleh langsung dari perusahaan berupa data mentah yang perlu diolah lagi, dalam hal ini data yang diperoleh dari hasil observasi dan wawancara berupa catatan dan dokumen yang diperoleh langsung dari PT. Bank Negara Indonesia (Persero) Tbk. Cabang Makassar yang dibutuhkan dalam penelitian.

\section{Data Sekunder}

Data sekunder merupakan data penunjang bagi penyusunan penelitian ini diperoleh dari informasi berupa buku, internet, literature lain atau data yang sudah ada seperti audit kepatuhan piutang tak tertagih yang diperoleh dari jurnal-jurnal penelitian yang telah ada sebelumnya.

\subsection{Pengumpulan Data}

Teknik pengumpulan data yang akan digunakan dalam penelitian ini adalah:

1. Penelitian kepustakaan

Penelitian kepustakaan dilakukan dengan cara melakukan telaah atas datadata sekunteknik observasi (pengamatan) dan teknik wawancara (Interview). Teknik observasi yaitu metode pengumpulan data dengan pengamatan secara langsung terhadap subjek dan keadaan perusahaan, serta kegiatan dilakukan perusahaan.

2. Penelitian lapangan

a. Observasi

Observasi dilakukan dengan mengumpulkan data-data tentang audit kepatuhan pengelolaan piutang melalui pengamatan langsung, tanpa alat-alat tertentu untuk keperluan penelitian.

b. Wawancara

Wawancara merupakan data yang dikumpulkan melalui interaksi secara langsung dari responden dengan mengadakan Tanya jawab guna memperoleh data yang diperlukan terutama kepada bagian Audit Internal perusahaan karena berhubungan dengan Audit pengelolaan piutang dalam meminimalkan piutang tak tertagih.

c. Dokumentasi

Yaitu teknik pengumpulan data dengan cara pencatatan dari dokumen perusahaan yang berhubungan dengan penelitian ini.

\subsection{Instrumen Penelitian}

Instrumen penelitian adalah ala bantu yang dipilih dan digunakan oleh 
peneliti dalam kegiatannya dalam mengumpulkan data agar kegiatan tersebut menjadi sistematis dan dipermudah. Jadi instrument penelitian ini adalah peneliti itu sendiri dan dibantu oleh beberapa alat yaitu kamera, buku, jurnal, serta beberapa dokumen.

\subsection{Teknik Analisis Data}

Teknik analisis data yang akan digunakan dalam penelitian ini adalah data kualitatif. Data yang telah diperoleh peneliti dari teknik dokumentasi dan wawancara selanjutnya peneliti melakukan kajian terhadap data tersebut. Dimana peneliti mengamati dan memeriksa audit kepatuhan dalam pengelolaan piutang tersebut dan memberikan saran kepada pihak perusahaan. Tahap akhir dalam menganalisis data pada penelitian ini yaitu menyimpulkan penelitian yang telah dilakukan sebagai hasil penelitian. Dalam menyimpulkan data, peneliti telah melalui barbagai tahapan tanpa melewatkan berbagai hal dari tahapan tersebut. Sehingga peneliti dapat menyimpulkan data dari hasil penelitian mengenai Audit kepatuhan pengeloaan piutang dalam meminimalisir piutang tak tertagih pada PT. Bank Negara Indonesia (Persero) Tbk. Cabang Makassar.

\section{HASIL DAN PEMBAHASAN}

\subsection{Hasil Penelitian}

\subsubsection{Kebijakan Akuntansi \\ Pelaksanaan Audit Kepatuhan}

Audit kepatuhan adalah suatu audit untuk memastikan bahwa pegawai yang terlibat dalam proses kredit sudah mematuhi standard atau prosedur yang ditetapkan bank BNI dan peraturan eksternal seperti Bank Indonesia dan Peraturan Pemerintah. Audit kepatuhan dapat menciptakan industry perbankan yang sehat, Fungsi kepatuhan adalah suatu fungsi yang memastikan bahwa kredit yang dikomitekan telah sesuai dengan pedoman yang telah ditetapkan, audit kepatuhan memperbaiki kulitas kredit khususnya pada PT Bank Negara Indonesia (Persero) tbk Cabang Makassar karena dengan audit kepatuhan ada beberapa risiko yang dimitigasi dari awal. Waktu yang diperlukan dalam proses audit kepatuhan khususnya sebelum kredit dicairkan sangat tergantung dari pengalaman yang dimiliki oleh pegawai yang melakukan dan wawasan beliau dalam mengetahui dan mengaplikasikan pedoman bank BNI dan peraturan Bank Indonesia.

Dalam pelaksanaan fungsi kepatuhan Bank berpedoman kepada Peraturan Bank Indonesia (PBI) Nomor 13/2/PBI/2011 tentang pelaksanaan fungsi kepatuhan Bank Umum dan kebijakan intern Bank PT Bank Negara Indonesia (Persero) Tbk. Cabang Makassar telah mempunyai suatu perangkat audit kepatuhan yang dinamakan Credit Compliance Review (C2R) yang berfungsi untuk memastikan bahwa risiko ketidakpatuhan dalam proses pengelolaan piutang dapat diketahui sebelum suatu fasilitas kredit dikomitekan sehingga kerugian financial akibat ketidakpatuhan dapat diatasi dari awal sejak sebelum pemberian kredit dengan menggunakan aturan-aturan yang sifatnya mengikat, dengan melihat prosedur yang diterapkan oleh bank dalam pemberian kredit dimulai dari calon debitur mengajukan permohonan kredit tertulis, pihak marketing memeriksa kelengkapan berkas nasabah, apabila telah disetujui oleh bagian analisis kredit, selanjutnya bagian legal officer memberikan semua data pemberian kredit telah disetujui kepada notaris 
untuk dibuatkan pengikatan kredit beserta agunannya untuk ditandatangani antara pihak bank dan nasabah. Direktur kepatuhan dengan dibantu Group Kepatuhan telah mengeluarkan beberapa kebijakan untuk menciptakan budaya kepatuhan dan peningkatan kualitas penerapan fungsi kepatuhan.

\section{a. Prosedur Pemberian Kredit}

Risiko ketidakpatuhan dapat diidentifikasi pada awal kredit sehingga kerugian kerugian financial dapat dihindari, misalnya pemberian fasilitas kredit yang dilarang oleh pemerintah. Ketiadaan pedoman atau lambatnya up date akan sangat berpengaruh pada unit kepatuhan.

\section{b. Prosedur Pengelolaan piutang}

Pengelolaaan piutang pada PT Bank Negara Indonesia (Persero) tbk Cabang Makassar melakukan pengklasifikasian, yaitu dengan status kolektibilitas Lancar yang merupakan status kolektibilitas tertinggi dan ditandai dari riwayat pembayaran angsuran bunga atau angsuran pokok dan bunga kredit tiap bulannya tepat atau kurang dari tanggal jatuh tempo pembayaran bulanannya (tanpa cela).

Status kolektibilitas dalam perhatian khusus merupakan status kolektibilitas yang ditandai oleh keterlambatan membayar debitur melebih tanggal jatuh tempo atau 1-2 bulan lamanya, ketika terjadi hal tersebut maka pihak Bank melakukan penagihan biasa atau melaksanakan restruksi tergantung kesepakatan antara debitur dengan kreditur. Status Kolektibilitas kurang lancar merupakan status kolektibilitas debitur yang lambat membayar lebih dari 60 hari sejak jatuh tempo bulannya sampai sekurangkurangnya 120 hari atau selambat- lambatnya 3-4 bulan lamanya, ketika terjadi hal demikian pihak bank mengeluarkan Surat peringatan (SP) dan mulai melakukan perhitungan akrual terhadap tunggakan pokok dan bunga berjalan, tunggakan administrasi pembukuan.

Status kolektibilitas diragukan yang menandakan keterlambatan membayar melebihi 120 hari sejak tanggal jatuh tempo bulanannya atau maksimum 4 bulan keatas, ketika terjadi hal demikian pihak bank melakukan pelelangan agunan dan mengeluarkan SP 2 kepada nasabah. Status kolektibilitas Macet tergolong NonPerforming Limit (NPL) yang merepresentasikan angsuran pokok dan bunga kredit tidak terbayarkan dan bank berkewajiban melaksanakan penyelesaian kredit bermasalah paling terakhir yaitu melakukan melelang agunan. Kemudian hasil dari penjualan bank hanya mengambil uang pokonya saja, selebihnya dikembalikan kepada nasabah.

Pengendalian Risiko Kredit dilakukan dalam rangka mencegah terjadinya kerugian yang lebih mendalam untuk itu Bank BNI telah memiliki Loan Exposure Limit (LEL) yang berfungsi membatasi risiko konsentrasi pinjaman setiap sector ekonomi dan masing-masing segmen, dan menjadi pedoman ekspansi pinjaman.

PT Bank Negara Indonesia (Persero) tbk Cabang Makassar melakukan Follow up terhadap piutang yang belum dibayarkan kepada pihak yang bersangkutan, perusahaan memberikan pengendalian piutang yang baik dan benar serta dilakukan pengawasan yang ketat dan evaluasi secara berkala.

Sistem pengarsipan dokumen dilakukan secara sistematis sehingga memudahkan karyawan dalam mencari 
data-data mengenai Nasabah debitur yang ditanganinya. Internal Control untuk proses pemberian kredit yang ada pada PT Bank Negara Indonesia (persero) Tbk. Cabang Makassar juga sudah baik. Setiap pencairan dana yang diberikan telah melalui prosedur yang ditetapkan dan analisis yang dilakukan mencakup pemeriksaan kelengkapan dokumen debitur serta peninjauan langsung kepada debitur.

\subsection{Pembahasan}

Berdasarkan pada hasil penelitian dapat diketahui bahwa audit kepatuhan dalam pengelolaan piutang dalam meminimalisir piutang tak tertagih pada PT Bank Negara Indonesia (Persero) Tbk. Cabang Makassar telah dilaksanakan dengan baik. Adapun hasil pembahasan dari peneliti yaitu PT Bank Negara Indonesia (Persero) Tbk. Cabang Makassar sangat penting diadakan audit kepatuhan pelaksanaan terhadap pengelolaan piutang yang berfungsi untuk mengurangi risiko-risiko baik yang bersifat preventif maupun kuratif.

PT Bank Negara Indonesia (Persero) Tbk. Cabang Makassar telah mempunyai suatu perangkat audit kepatuhan yang dinamakan Credit Compliance Review (C2R) yang berfungsi untuk memastikan bahwa risiko ketidakpatuhan dalam proses pengelolaan piutang dapat diketahui sebelum suatu fasilitas kredit dikomitekan sehingga kerugian financial akibat ketidakpatuhan dapat diatasi dari awal sejak sebelum pemberian kredit dengan menggunakan aturan-aturan yang sifatnya mengikat.

Pelaksanaan fungsi kepatuhan PT Bank Negara Indonesia (Persero) Tbk. Cabang Makassar dalam proses pemberian kredit telah dilakukan oleh
Regional Compliance Group, hal ini sejalan dengan peraturan Bank Indonesia Nomer 13/2/PBI/2011 tanggal 12 januari 2011 tentang pelaksanaan fungsi kepatuhan Bank Umum. Pelaksanaan fungsi kepatuhan dapat dilihat sebagai dari PT Bank Negara Indonesia (Persero) Tbk. Cabang Makassar telah mewujudkan budaya kepatuhan pada semua tingkatan organisasi dan kegiatan usaha bank, termasuk dalam pengelolaan piutang, telah mengelolah risiko kepatuhan,telah memastikan kebijakan, ketentuan, sistem dan prosedur serta kegiatan usaha yang dilakukan telah sesuai dengan ketentuan Bank Indonesia dan peraturan perundang-undangan yang berlaku.

PT Bank Negara Indonesia (Persero) Tbk. Cabang Makassar mulai dari sejak awal pemberian kredit sampai setelah pencairan kredit, dilakukan pengarsiapan yang secara sistematis sehingga mendukung bukti yang memadai ketika Kantor akuntan Publik datang melakukan pemeriksaan. PT Bank Negara Indonesia (Persero) Tbk. Cabang Makassar juga telah memiliki sebuah pedoman sehingga memudahkan dalam pekerjaannya.

PT Bank Negara Indonesia (Persero) Tbk. Cabang Makassar setelah pengajuan pinjaman tersebut disetujui oleh pihak Bank selalu memeriksa kondisi dari Debiturnya, memantau aktivitas penggunaan dana yang dilakukan oleh Debitur, serta memberikan pembinaan. Apabila terjadi tidak tercapainya target, maka Officer bank segera melakukan tindakan seperti turun langsung ke lapangan menemui Nasabah untuk mengetahui permasalahan yang dialami Nasabah, kemudian memberikan solusi penyelesaian masalah kepada Nasabah. 
Pengendalian terhadap piutang dapat menjamin manajemen perusahaan agar tujuan perusahaan dapat dicapai, Penelitian ini sesuai dengan penelitian yang dilakukan oleh Anny Widiasmara (2014) bahwa dengan dilakukannya pengendalian intern terhadap piutang usaha dan kualitas perbaikan terus menerus serta membukukan profit sesuai dengan tujuan yang ditetapkan oleh perusahaan ini diniliai mampu meminimalkan piutang tak tertagih hal ini sejalan dengan yang terjadi pada PT Bank Negara Indonesia dengan melaksanakan fungsi audit kepatuhan dalam pengelolaan piutang, yaitu dapat dilihat dari awal pemberian kredit sampai diberikannya kredit kepada nasabah serta dalam pengelolaannya dilakukan secara sistematis sesuai dengan pedoman perusahaan dapat meminimalisir piutang tak tertagih. Sama halnya dengan penelitian yang dilakukan oleh Manik Cahyarini (2015)

\section{PENUTUP}

\subsection{Simpulan}

Audit Kepatuhan yang dilaksanakan oleh Direktur Kepatuhan dan Satuan Kerja Kepatuhan telah berjalan dengan baik sesuai dengan tugas dan kewenangannya dan menjaga independensinya dengan baik karena memiliki pedoman kerja, sistem dan prosedur kerja yang telah mengacu kepada ketentuan perundang-undangan yang berlaku.

Kemudian mengenai pengelolaan piutang pada PT Bank Negara Indonesia (Persero) Tbk. Cabang Makassar sudah sesuai dengan standar operasional perusahaan yaitu mengambil keputusan mengenai standar kredit seorang pemohon dengan mengikuti prosedur pemberian kredit, kemudian memberikan syarat kredit dengan menetapkan priode dimana kredit diberikansetelah itu melakukan follow up terhadap nasabah agar menghindari resiko piutang tak tertagih.

Maka dari itu Penulis mengambil kesimpulan bahwa dengan dilakukakannya Audit kepatuhan pengelolaan piutang dapat berfungsi efektif dalam meminimlaisir piutang tak tertagih pada PT Bank Negara Indonesia (Persero) Tbk. Cabang Makassar hal dapat di lihat ketentuan Peraturan Bank Indonesia dan undang-undang sudah sesuai.

\subsection{Saran}

Berdasarkan hasil analisa dan juga pembahasan pada bab-bab sebelumnya dan pengamatan yang penulis lakukan. Berikut ini beberapa saran dari penulis diantaranya sebagai berikut:

1. Grup Kepatuhan melakukan sentralisasi mengenai peraturan perundang-undangan maupun regulasi yang berkaitan baik dari Bank Indonesia, Otoritas Jasa Keuangan dan instansi terkait lainnya khususnya ketentuan regulasi baru untuk dimonitor apakah ada ketentuan baru terkait dengan benturan kepentingan.

2. Dewan Komisaris menyelenggarakan pelatihan/workshop bagi Komitekomite untuk meningkatan pengetahuan agar dapat melaksanakan tugasnya dengan efektif untuk mendukung pelaksanaan tugas Dewan Komisaris.

3. Komponen-komponen dalam perangkat audit kepatuhan dibuat dalam sistem computer online sehingga jika terdapat perubahan ketentuan baik peraturan internal bank BNI dan peraturan eksternal dari otoritas yang berwenang khususnya 
peraturan Bank Indonesia dapat dengan cepat terupdate keseluruh unit kepatuhan.

\section{DAFTAR PUSTAKA}

Agoes, Sukrisno. 2012. Auditing Petunjuk Praktis Pemeriksaan Akuntan oleh Kantor Akuntan Publik. Edisi 4. Buku 1. Jakarta: Salemba Empat.

Anny Widiasmara. 2014. Analisis Penegndalian Intern Piutang Usaha Untuk Meminimalkan Piutang Tak Tertagih (Bad Debt) Pada Pt. Wahanaottomitra Multiartha, Tbk Cabang Madiun. jurnal STIE Dharma Iswara Madiun Volume 10, Nomor 2, juni 2014

Cahyarini M. 2015. Analisis Umur Piutang Untuk Meminimalisir Piutang Tak Tergih Pada PT. Bisma Karang Pilang Surabaya. Cendekia Akuntansi Vol.3 No. 3 September 2015

Costa, F. D. 2015. Analisis Kerugian Piutang Tak Tertagih Pada PT. Metta Karuna Jaya Makassar. Jurnal EMBA. vol.3 No.1 maret 2015

Drs. Sudarmo, M.M. 2014. Audit Kepatuhan Terhadap Standard Operating Procedure (SOP) Fortune Club pada PT. Lestari Entertaiment. Ganesha Triadi Pratama. Binus University

Erdi Kurniawan Syahputera \& Siti Khairani. 2012. Analisis Piutang tak tertagih pada PT. Bima Finance Palembang. jurnal STIE MDP. Jurusan Akuntansi Hal 1-9

Haryono Jusup. 2012. Dasar-dasar Akuntansi, edisi 7 YKPN, yogyakrta.

Ikatan Akuntan Indonesia. 2008. Pernyataan Standar Akuntansi Keuangan Cetakan Kedua. Jakarta: Salemba Empat.
Junaidi \& Cherrya. 2012. Audit Ketaatan prosedur pengelolaan piutang dalam meminimalisir piutang tak tertagih pada PT. Calmic Indonesia Cabang Palembang. jurnal STIE MDP jurusan akuntansi hal 1-9

Lukiento Cahyadi, SE, MM, 2014. Analisis Prosedur Pemberian Kredit Pada PT. BPR Nusantara Bona Pasogit 18 Cabang Tebing Tinggi. Jurnal Ilmaih Accounting Change STIE Bina Karya Tebing Tinggi. Volume 2, No.2

Narbuko Cholid dan H. Abu Achmadi. 2012. Metodolgi Penelitian. Jakarta: Bumi Aksara,

Peraturan mentri keuangan (No.84/PMK.012/2006)

Rivai Veithzal, dkk. 2013. Manajemen Perbankan Dari Teori Ke Praktik. Jakarta: Raja Grafindo Persada.

Ronald David A. Irot, Herman Karamoy dan Lidia Mawikere. 2013. Pelaksanaaan Audit Kepatuhan Dalam Proses Pemberian kredit di PT. Bank Negara Indonesia (Persero) Tbk, Sentra Kredit Menengah Manado. Jurnal Riset Akuntansi dan Auditing Magister Akuntansi Fakultas Ekonomi Unsrat. Volume 4 Nomer 2. 